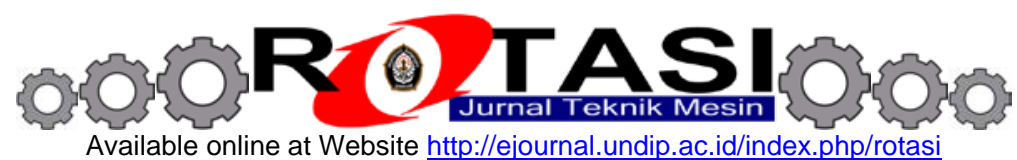

\title{
Desain dan Simulasi Frame dan Bodi Kendaraan Konsep Urban Menggunakan Software CAD
}

\author{
*Agus Mukhtar, Yuris Setyoadi, Aan Burhanuddin \\ Jurusan Teknik Mesin, Fakultas Teknik, Universitas PGRI Semarang \\ Jalan Sidodadi Timur Nomor 24 Semarang - Indonesia 50125 \\ *E-mail: agus.mukhtar@gmail.com
}

\begin{abstract}
Abstrak
Mobil urban adalah mobil yang mesin dan dimensinya didesain untuk jalan raya di kota besar karena jalanan di kota besar karena biasanya padat dan macet. Mobil mungil ini bisa dipakai untuk menghemat bahan bakar minyak (BBM) karena memang konsumsinya tidak sebesar mobil jenis lain [1]. Salah satu hal yang perlu diperhatikan dari mobil urban adalah segi kekuatan dari rangka/frame yang menerima beban oleh beberapa komponen diantaranya, pengemudi, mesin penggerak, body dan baterai. Simulasi beban statik casis dan simulasi aerodinamis dari bodi kendaraan dilakukan dengan menggunakan software Solidworks yang dilakukan pada rangka dengan dari baja kontruksi jenis $\mathrm{Al}$ 6061 dan body fiber. Hasil analisis dan simulasi, displacement maksimal beban bodi pada casis sebesar 3,77 mm dan von Mises Stresses beban bodi pada casis sebesar 2,17 N/mm2. Displacement maksimal beban penumpang pada casis sebesar 4,42 mm dan von Mises Stresses beban bodi pada casis sebesar 0,32 N/mm2. Flow simulation pada kecepatan angin $11.12 \mathrm{~m} / \mathrm{s}$ diperoleh gambar tekanan, dimana terdapat tekanan yang tinggi pada bagian ujung depan bodi dengan nilai tekanan maksimal yang terdapat pada color bar adalah sebesar 101.561,12 $\mathrm{Pa}$.
\end{abstract}

Kata kunci: Desain dan Simulasi, Frame, Bodi, Urban, Software CAD

\section{Pendahuluan}

Bila kita melihat sejarah ditemukannya mobil dimana saat itu, tahun 1885, seorang Insinyur dari Jerman, Karl Benz, menemukan sebuah konsep sederhana dari sebuah mobil. Sebenarnya apa definisi dari mobil itu sendiri?. Tentu jawaban tidak sekedar mobil adalah sebuah benda yang terbuat dari metal dengan roda pada setiap sudutnya. Namun secara lebih spesifik bisa dijelaskan bahwa mobil adalah sebuah energi converter, sebuah mesin yang melepaskan energi yang terkunci dalam bahan bakar, seperti bensin atau solar dan mengubahnya menjadi sebuah energi mekanik untuk menggerakkan roda dan gigi. Begitulah penjelasan singkat mengenai cara kerja mesin mobil [2].

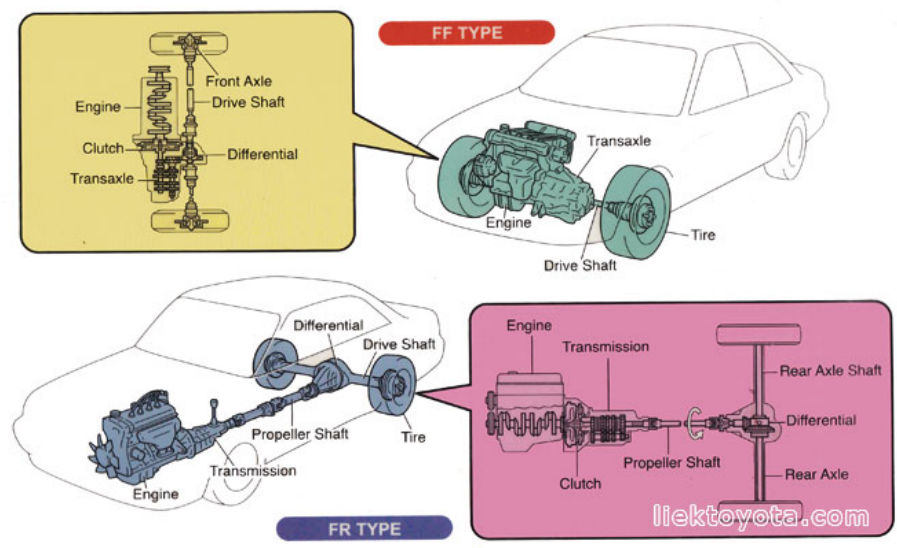

Gambar 1. Sistem penggerak mobil [3]

Ada banyak bagian dari mobil yang mempengaruhi kinerjanya, antara lain casis dan pemindah tenaga. Casis merupakan bagian paling dasar yang berfungsi mendukung mesin, suspensi, dan bagian-bagian lainnya, Casis menentukan stabilitas dan kenyamanan kendaraan. Sedangkan pemindah tenaga merupakan seluruh komponen yang terkait secara langsung dalam proses pemindahan tenaga dari motor penggerak sampai ke roda/wheel.

Aerodinamika untuk mobil menjadi aspek yang sangat diperhatikan dalam desain bodi mobil. Dengan aerodinamika mobil yang tepat, akan dapat mengoptimalkan engine power untuk menjadi daya dorong dan traksi mobil, hemat bahan bakar dan terjaminnya stabilitas mobil. Semakin cepat jalannya mobil, secara umum akan meningkatkan gaya aerodinamika yang terjadi pada mobil meliputi gaya hambat (drag force) aerodinamik, gaya angkat (lift force) aerodinamik dan gaya samping (side force) aerodinamik [4]. 


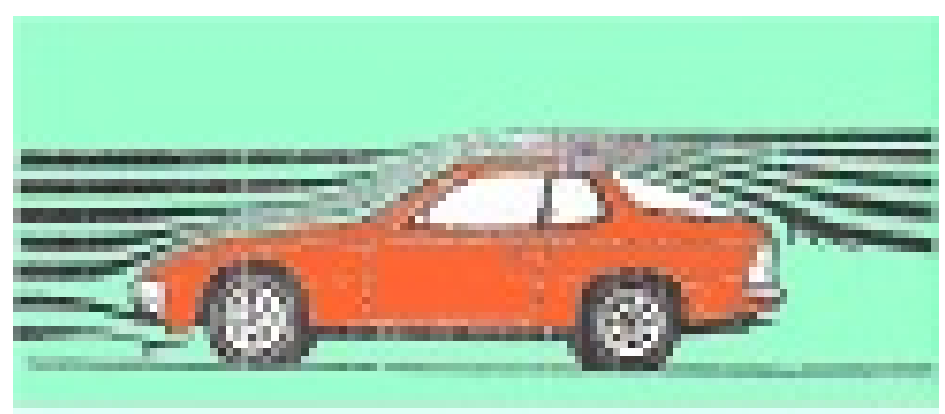

Gambar 2. Aerodinamika mobil

Bagian dari mobil yang mempengaruhi kinerjanya antara lain casis dan bodi. Casis merupakan bagian paling dasar yang berfungsi mendukung mesin, suspensi dan bagian-bagian lainnya, Casis menentukan stabilitas dan kenyamanan kendaraan. Desain bodi mobil dengan aerodinamika mobil yang tepat akan dapat mengoptimalkan engine power untuk menjadi daya dorong dan traksi mobil, hemat bahan bakar dan terjaminnya stabilitas mobil [5].

\section{Material dan metode penelitian}

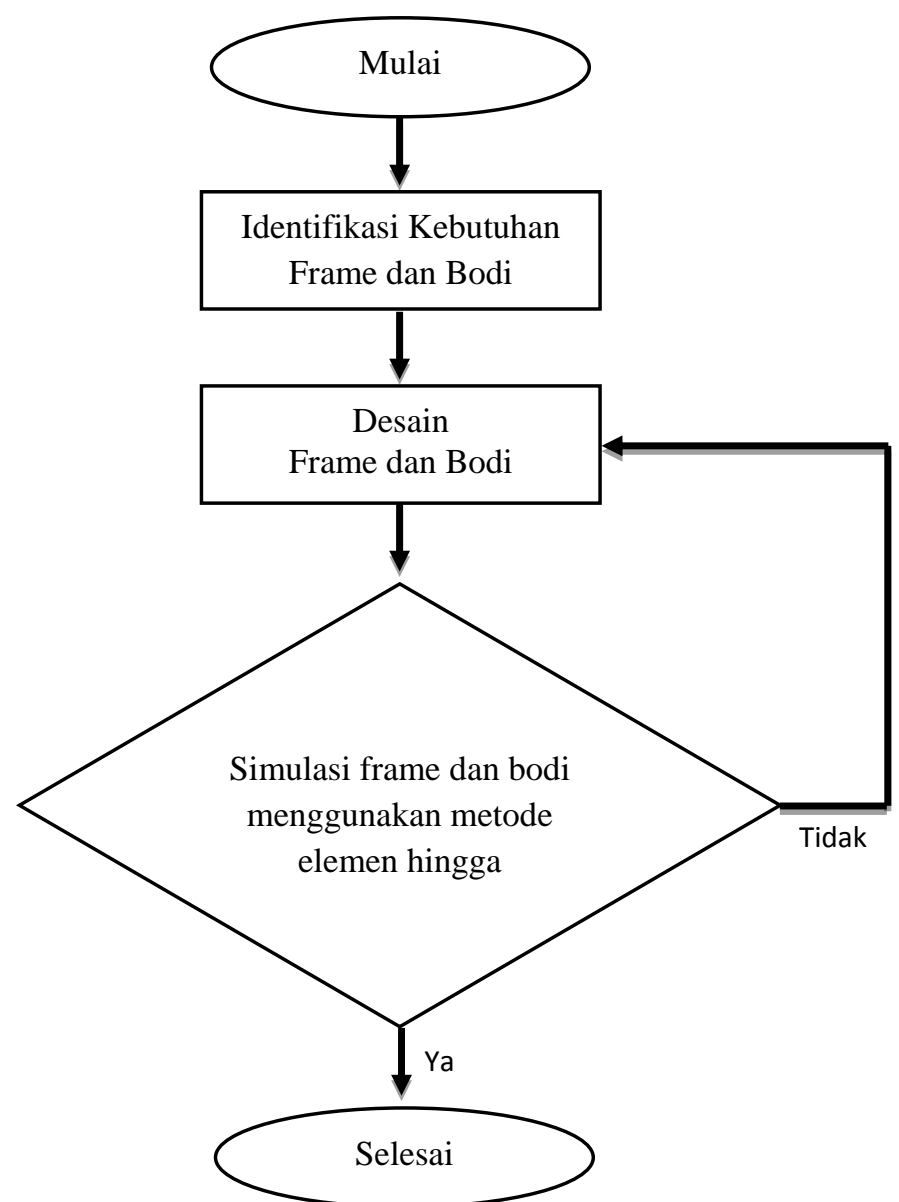

Gambar 3. Diagram alir proses rancang bangun frame dan bodi

Identifikasi kebutuhan dilakukan dengan cara mencari literatur kebutuhan komponen dan desain casis dan bodi kendaraan konsep urban. Spesifikasi casis dan bodi kendaraan konsep urban antara lain:
a. Kinerja
b. Dimensi
c. Kondisi operasi
d. Harga

Desain casis dan bodi kendaraan konsep urban dibuat sesuai peraturan kelas konsep urban yang berlaku. Proses desain casis dan bodi kendaraan konsep urban didapat bentuk model dan dimensi, dengan material bodi serat fiber dan 
resin, casis menggunakan material AL 6061 [6]. Proses desain dilakukan menggunakan software Solidworks 2016. Desain casis dan bodi kendaraan konsep urban ditunjukkan pada Gambar 4 dan 5.

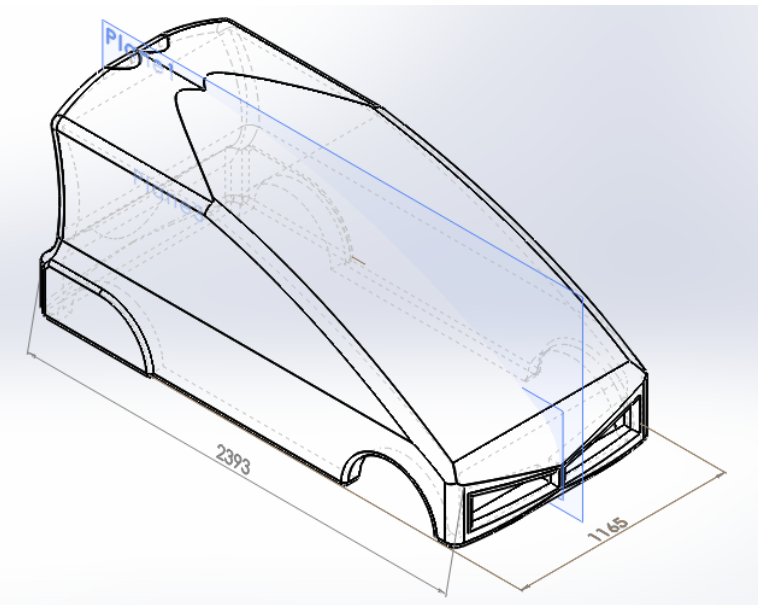

Gambar 4. Desain bodi kendaraan konsep urban.

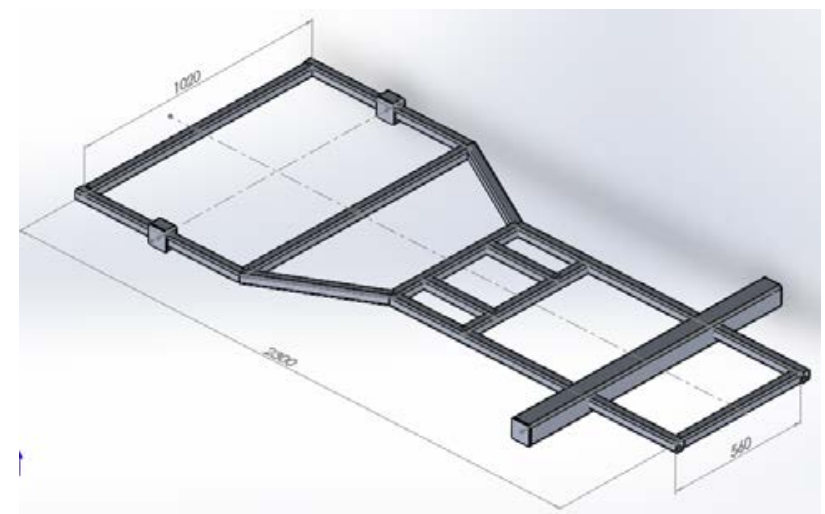

Gambar 5. Desain casis kendaraan konsep urban.

Detail desain casis dan bodi kendaraan konsep urban hasil assembling ditunjukkan pada Gambar 6.

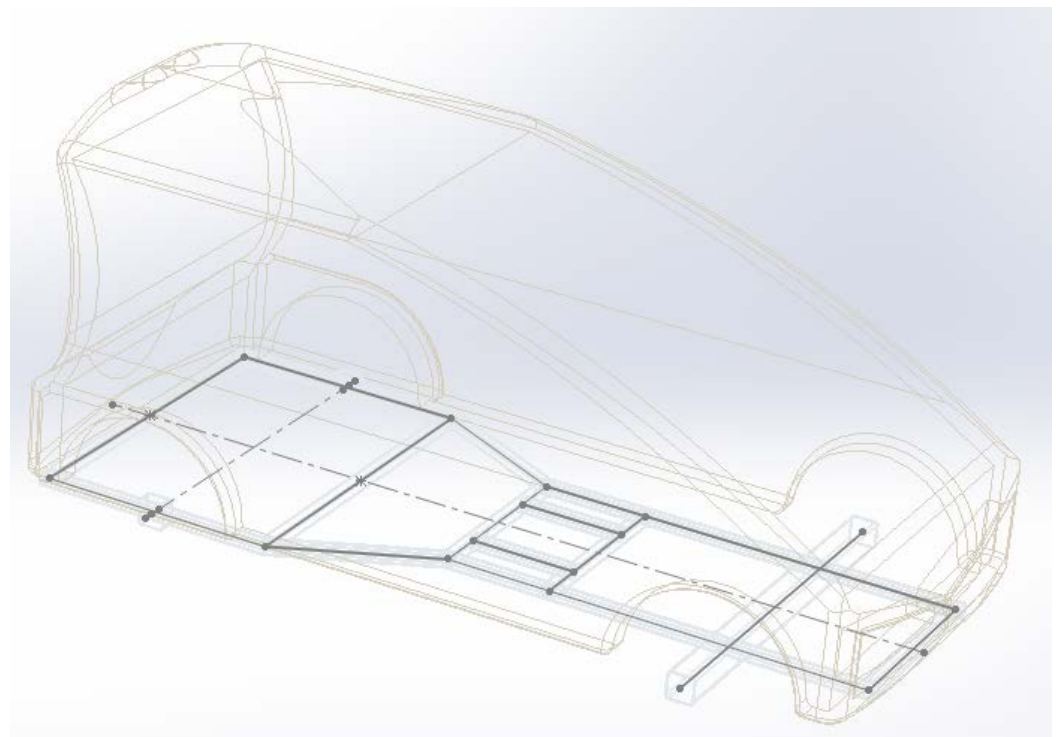

Gambar 6. Desain casis kendaraan konsep urban hasil assembling

Simulasi beban statis pengendara pada rangka mobil konsep urban dan simulasi aerodinamika bodi menggunakan metode elemen hingga (finite element method), untuk mendapatkan mekanika kekuatan material casis, 
keaerodinamisan bodi dan detail mekanis desain atau gambar kerja yang akan dibuat, dilanjutkan proses manufaktur casis dan bodi, kemudian dilakukan perakitan antara casis dan bodi.

Khusus dalam penelitian ini rancangan casis dan bodi kendaraan konsep sebagai bagian dari objek penelitian dengan menekankan pada subjek displacement, stresses pada konstruksi rancangan casis dan bodi kendaraan konsep menggunakan software engineering Solidworks 2016. Dalam proses analisis dan simulasi selain desain atau bentuk model yang akan dianalisis serta beban yang dikenakan pada model desain, juga harus menentukan jenis material dari model desain.

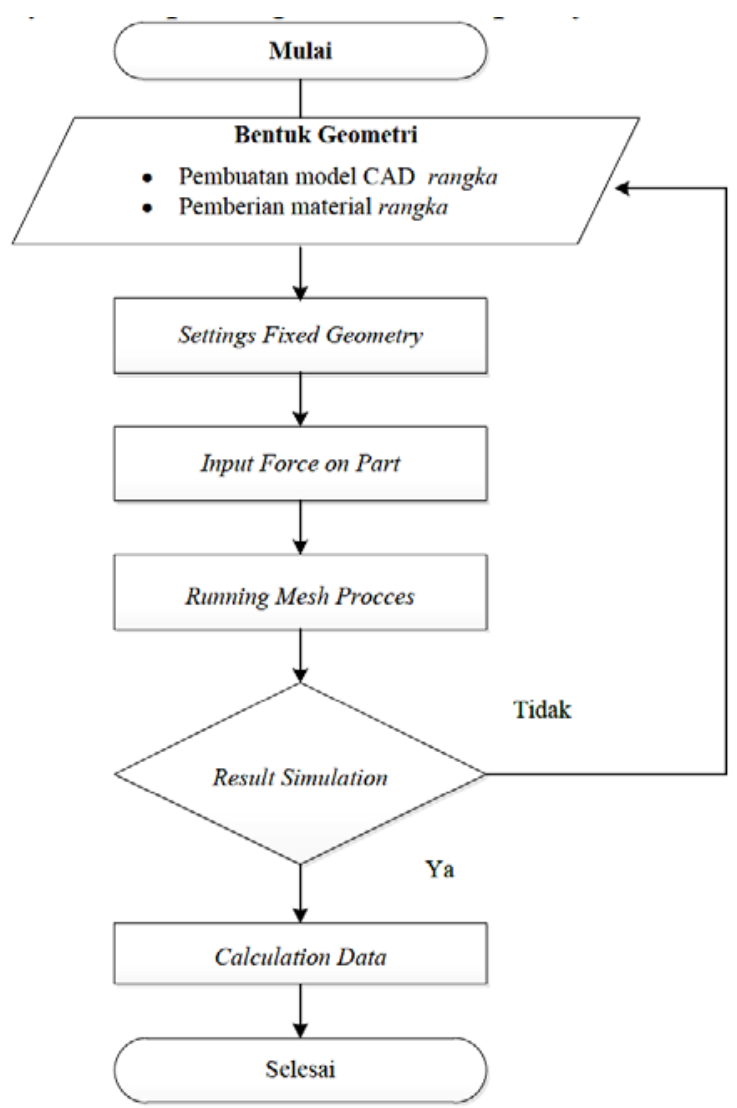

Gambar 7. Diagram alir simulasi casis kendaraan konsep urban.

Urutan proses simulasi dilakukan pembebanan paada casis dengan 2 tahap, yaitu:

a. Pembebanan bodi pada casis

b. Pembebanan penumpang pada casis

Tahapan proses pembebanan bodi pada casis diperlihatkan pada proses berikut:

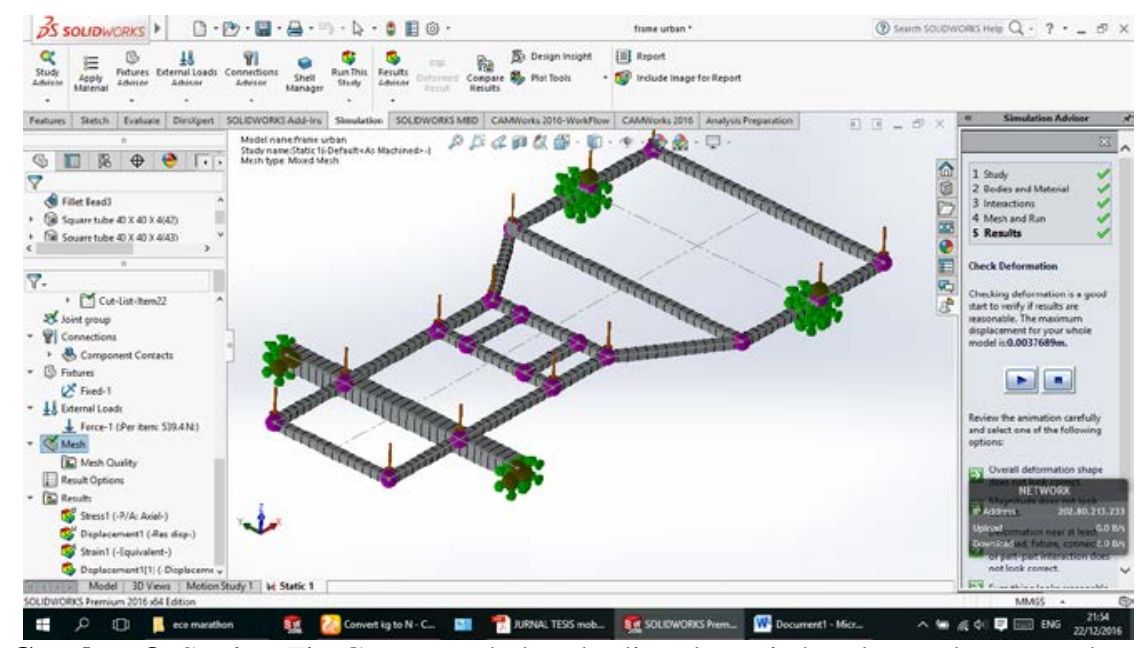

Gambar 8. Setting Fix Geometry beban bodi pada casis kendaraan konsep urban. 
Input Force On Part disesuaikan beban bodi yaitu 55 kg yang dikonversikan ke Newton menjadi 539,4 N.

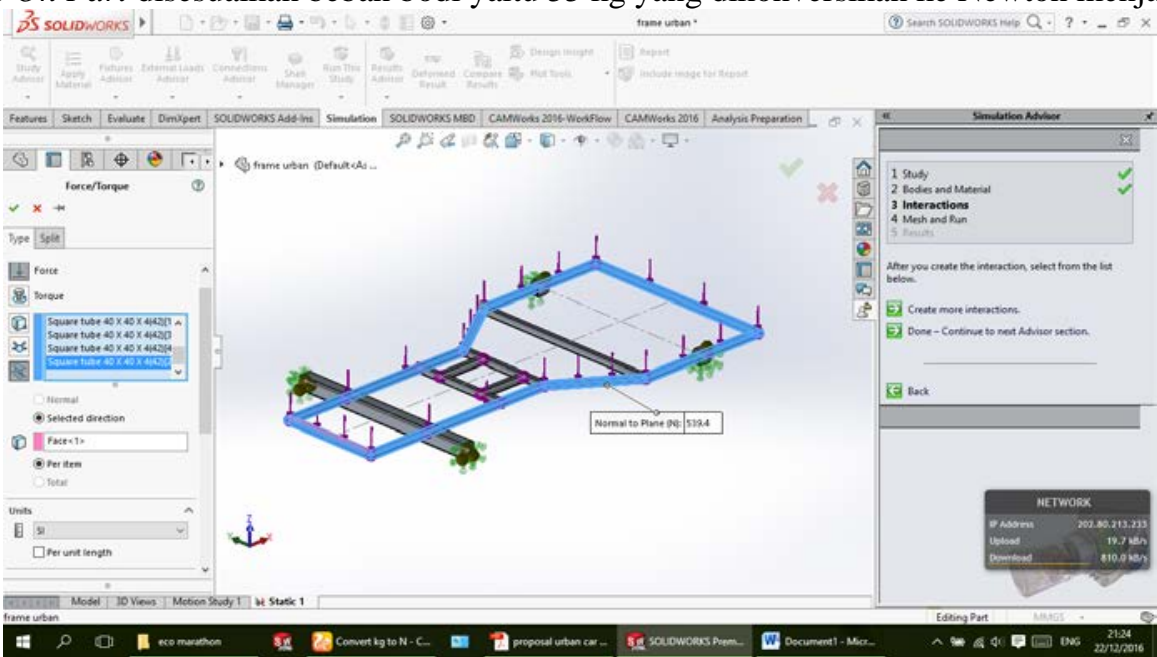

Gambar 9. Input Force On Part beban bodi pada casis kendaraan konsep urban.

Tahapan proses pembebanan penumpang pada casis diperlihatkan pada proses berikut:

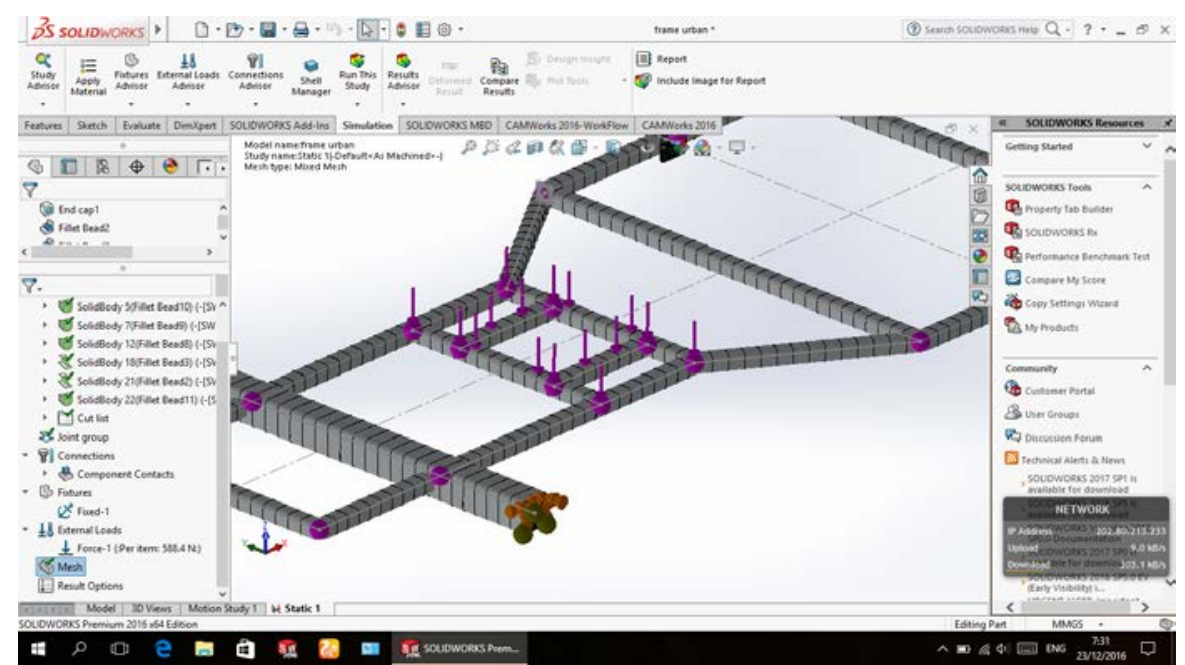

Gambar 10. Setting Fix Geometry beban penumpang pada casis

Input Force On Part disesuaikan beban penumpang yaitu $60 \mathrm{Kg}$ yang dikonversikan ke Newton menjadi 588,4N.

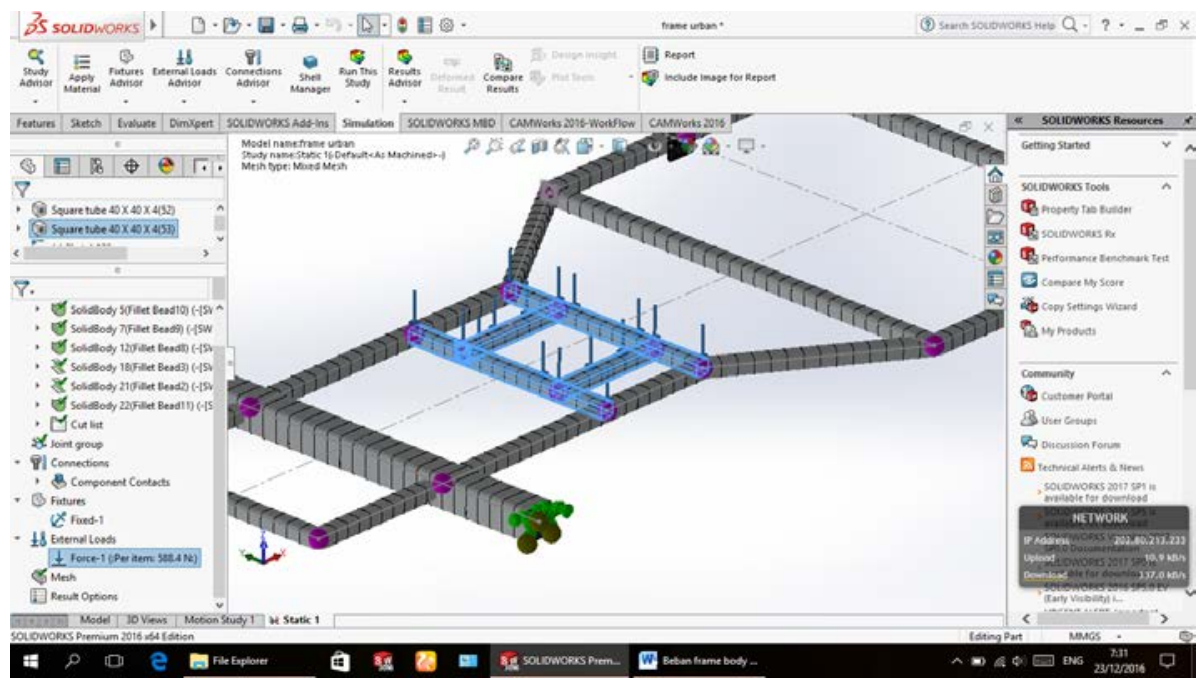

Gambar 11. Input Force On Part beban penumpang pada casis 


\section{Hasil dan pembahasan}

Hasil analisis dan simulasi casis dan bodi kendaraan konsep urban displacement dan stresses pada konstruksi rancangan casis dan bodi kendaraan konsep urban sebagaimana pada. Gambar 12 dan 13, yang merupakan adalah hasil displacement dan stresses pembebanan bodi pada casis, sedangkan Gambar 14 dan 15 adalah hasil displacement dan stresses pembebanan penumpang pada casis.

Displacement maksimal beban bodi pada casis sebesar 3,77 mm, stresses beban bodi pada casis sebesar 2,17 $\mathrm{N} / \mathrm{mm} 2$, hasil angka maksimal diperlihatkan pada grafik berwarna merah.

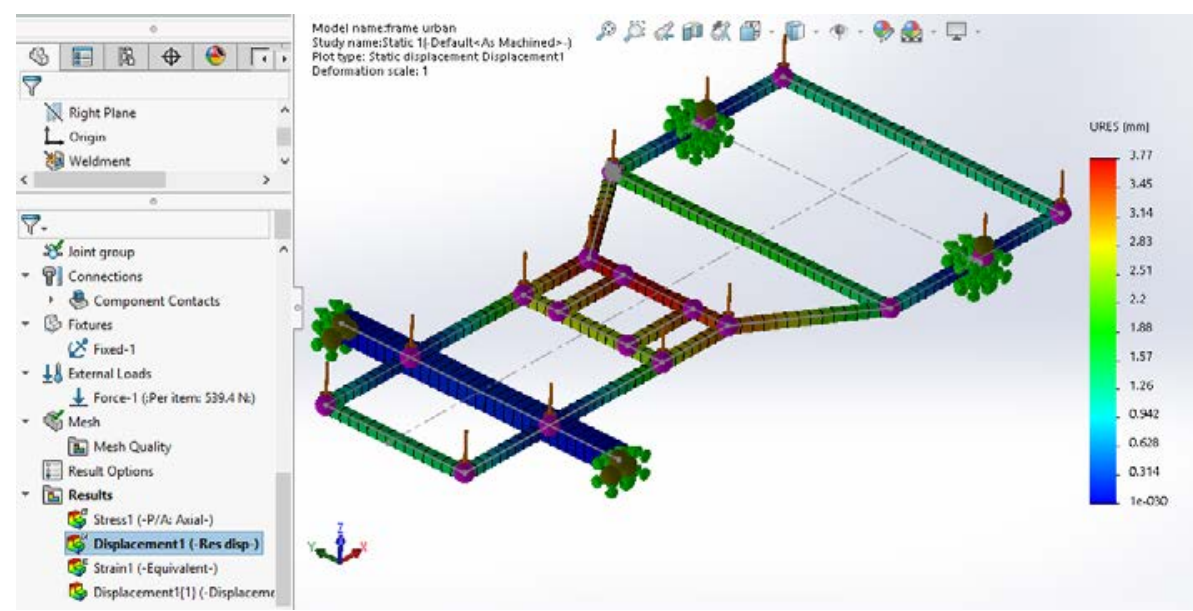

Gambar 12. Displacement beban bodi pada casis.

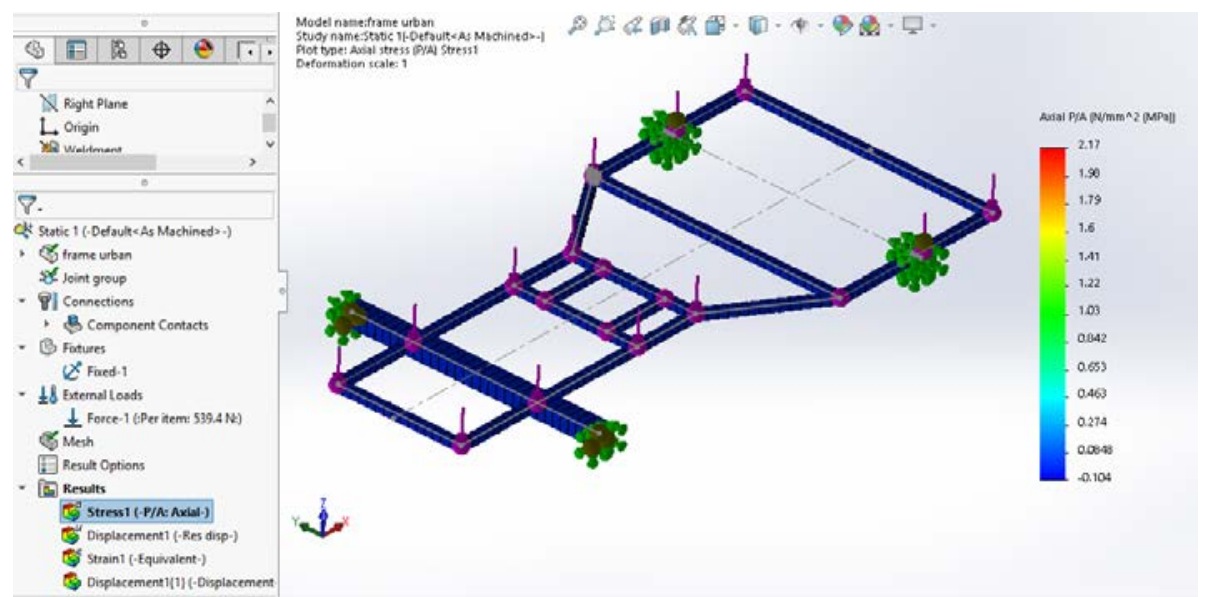

Gambar 13. Stresses beban bodi pada casis.

Displacement maksimal beban penumpang pada casis sebesar 4,42 $\mathrm{mm}$, stresses beban penumpang pada casis sebesar 0,32 N/mm2, hasil angka maksimal diperlihatkan pada grafik berwarna merah.

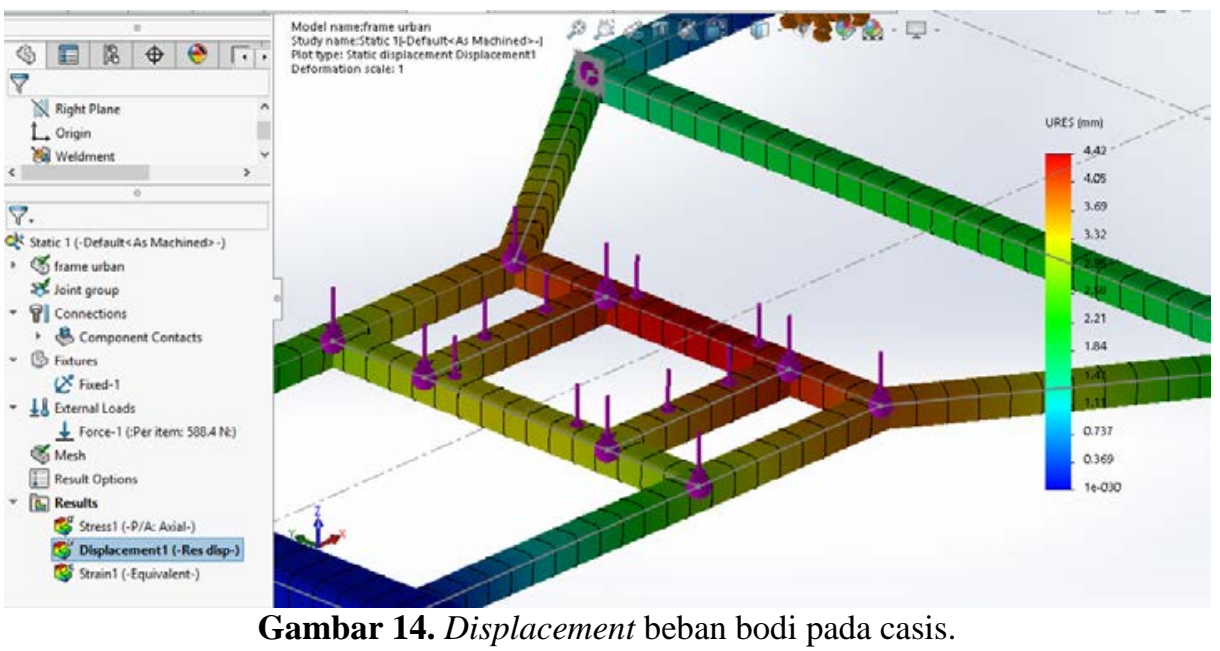




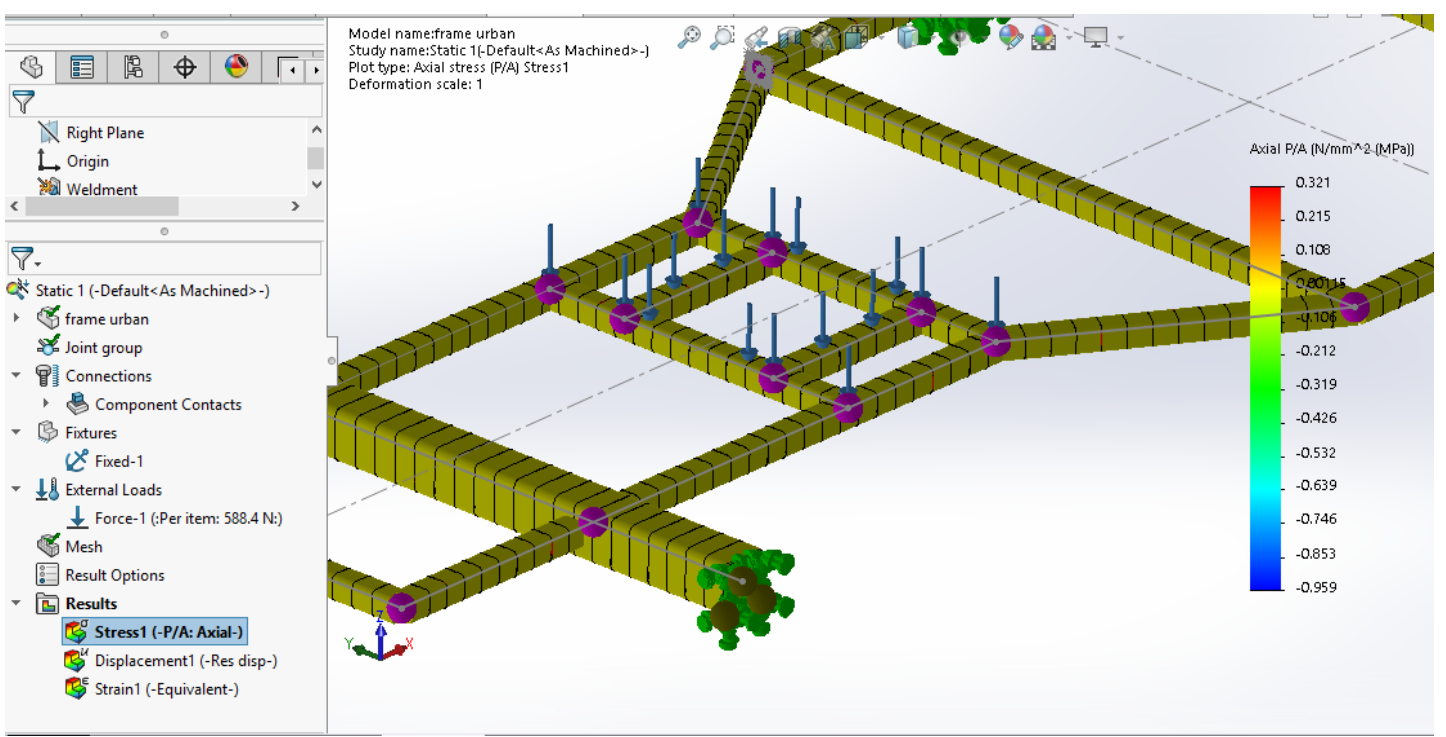

Gambar 15. Stresses beban bodi pada casis.

Hasil aplikasi run solver yang dipakai adalah flow simulation yang terdapat di Solidworks 2016. Dibawah ini gambar hasil run solver dengan konfigurasi meshing kecepatan dan tekanan. Pada kecepatan angin $11.12 \mathrm{~m} / \mathrm{s}$ di dapat gambar tekanan yang dihasilkan pada analisis, terdapat tekanan yang tinggi pada bagian ujung depan body yang bisa di lihat pada gambar yang berwarna kemerahan dengan nilai tekanan maksimal yang terdapat pada color bar adalah sebesar 101561,12 Pa.
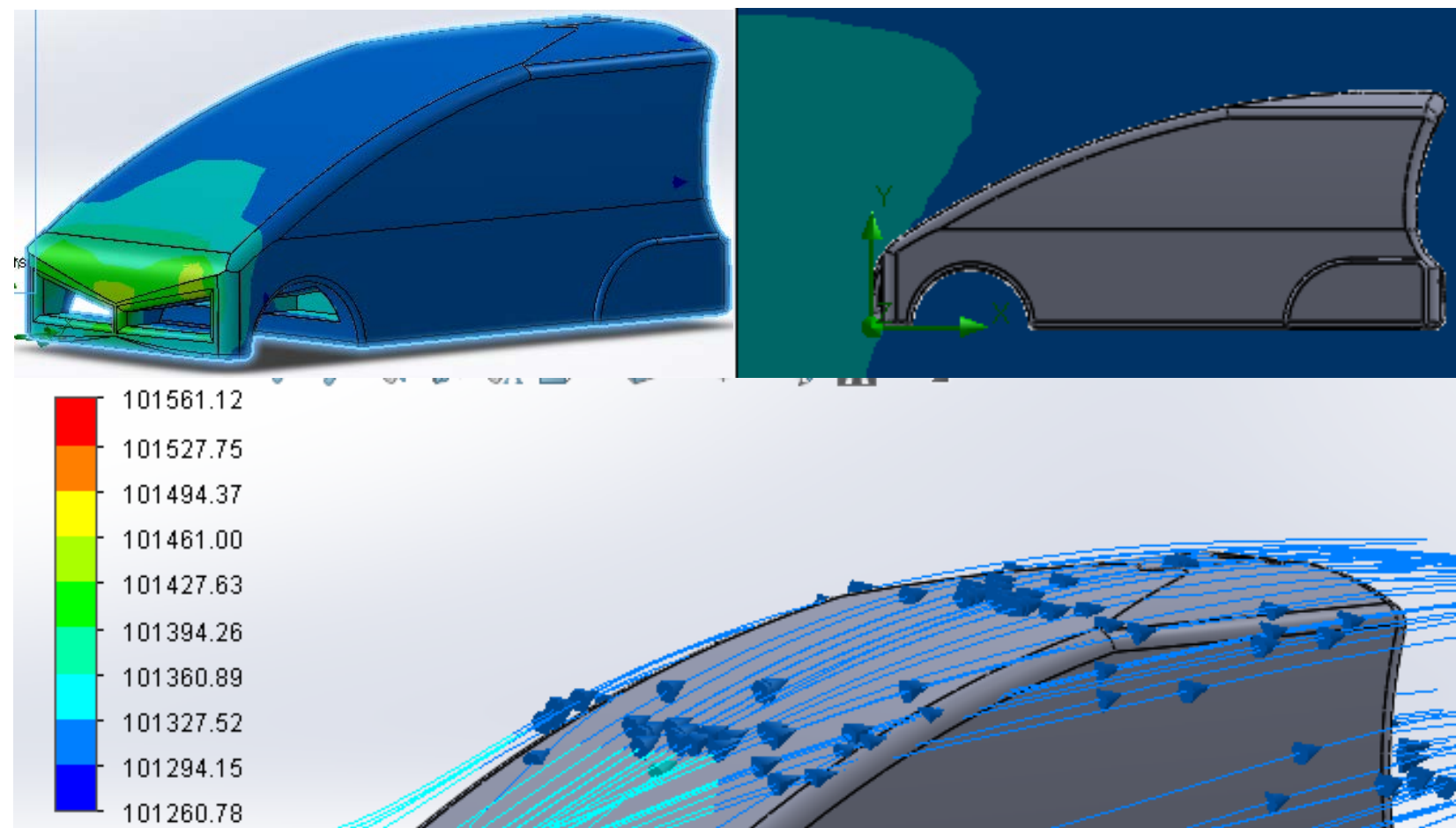

Pressure $[\mathrm{Pa}]$

Cut Plot 1: contōts:Surface Plot zugumouths Flow Trajectories 2

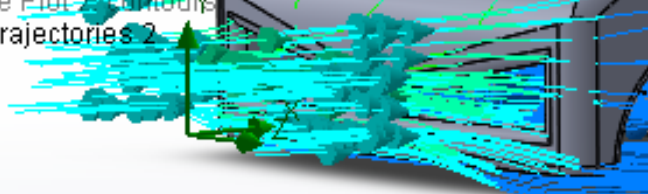

Gambar 16. Cut Plot Tekanan (Pressure) dengan Kecepatan 11.12 m/s. 


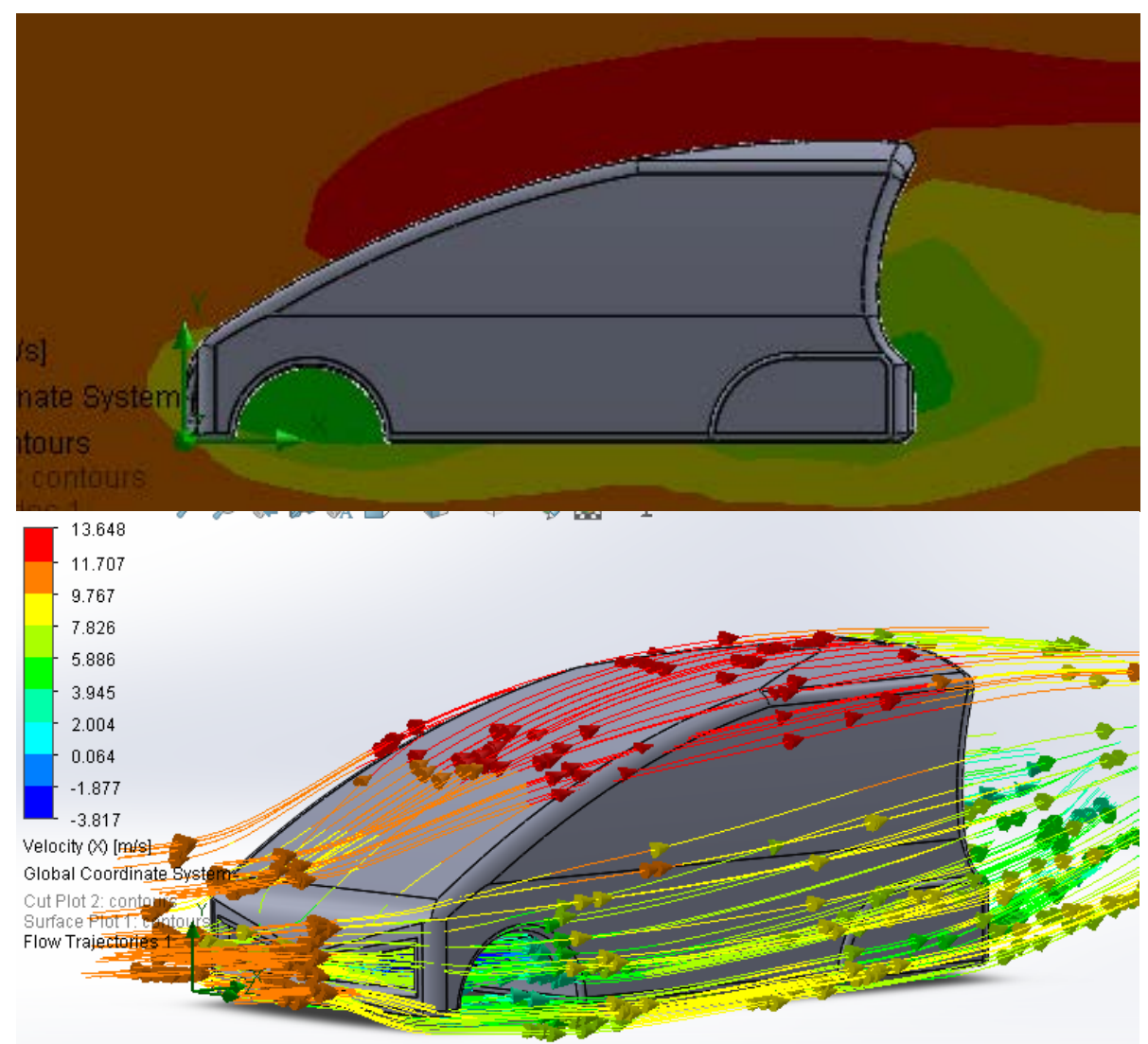

Gambar 17. Cut Plot Kecepatan (Velocity) dengan Kecepatan 11.12 m/s.

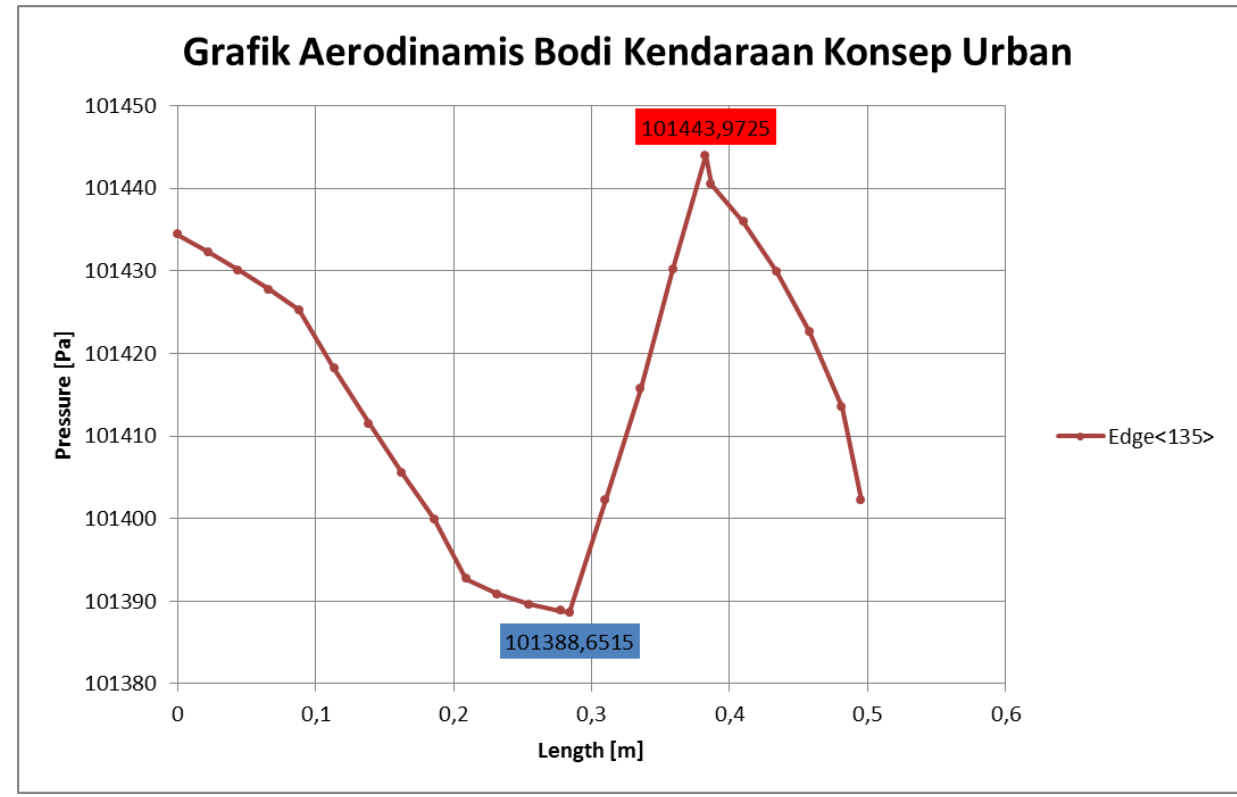

Gambar 18. Grafik Tekanan (Pressure) dengan Kecepatan $11 \mathrm{~m} / \mathrm{s}$

\section{Kesimpulan}

Berdasarkan hasil analisis dalam rancang bangun casis dengan material Al 6061 dan bodi dengan material serat fiber, kendaraan konsep urban menggunakan software Solidworks 2016.

a. Displacement maksimal beban bodi pada casis sebesar 3,77 mm, Von Mises Stresses beban bodi pada casis sebesar $2,17 \mathrm{~N} / \mathrm{mm} 2$, masih dibawah yield strength yang sebesar 55,14 N/mm2.

b. Displacement maksimal beban penumpang pada casis sebesar 4,42 mm, Von Mises Stresses beban bodi pada casis sebesar 0,32 N/mm2, masih dibawah yield strength yang sebesar 55,14 N/mm2. 
c. Flow simulation pada kecepatan angin $11.12 \mathrm{~m} / \mathrm{s}$ di dapat gambar tekanan yang dihasilkan pada analisis, terdapat tekanan yang tinggi pada bagian ujung depan bodi yang bisa di lihat pada gambar yang berwarna kemerahan dengan nilai tekanan maksimal yang terdapat pada color bar adalah sebesar 101.561,12 Pa.

\section{Referensi}

[1] Herdianto, A., 2013, "Perancangan Sistem Kemudi, Sistem Rem, Dan Roda Urban City Car Untuk Kompetisi Urbanconcept Shell Eco-Marathon”.

[2] Carapedia, “Cara Kerja Mesin Mobil,” http://carapedia.com, diakses: 14 Juli 2017.

[3] Anonim, 1995, “New Step 1 Training Manual”, Jakarta, PT. Toyota-Astra Motor.

[4] Usu, "Horas Team Won The Shell Eco Marathon Competition In Manila Philippine”, http://usu.ac.id, diakses: 14 Juli 2017.

[5] Daryanto, 2004, “Reparasi Casis Mobil”, Jakarta, PT Rineka Cipta dan PT Bina Adiaksara.

[6] Sapto, A., Yamin, M., 2014, "Permodelan, Simulasi Dan Rancang Bangun Prototype Kendaraan Hybrid”.

\section{Ucapan terima kasih}

Alhamdulillah dan Terima kasih kami ucapkan kepada LPPM UPGRIS yang telah memberikan fasilitas dan membantu pendanaan dalam melakukan penelitian ini. Tidak ketinggalan terima kasih kami ucapkan kepada rekan dosen dan mahasiswa yang telah membantu proses berjalannya penelitian ini. 